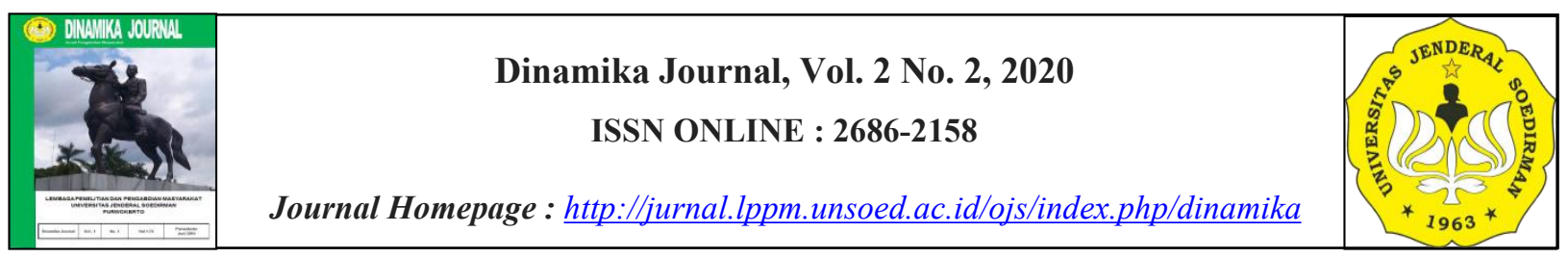

\title{
PELATIHAN PEMANFAATAN BARANG BEKAS DENGAN TEKNIK DECOUPAGE GUNA MENDORONG JIWA KEWIRAUSAHAAN DI RUMAH ASUH BAITII JANNATII
}

\author{
Muliasari Pinilih*, Septi Fajarwati, Agung Prasetyo \\ Fakultas Ilmu Komputer, Universitas Amikom, Purwokerto, Indonesia \\ ${ }^{*}$ Corresponding author : mpinilih@amikompurwokerto.ac.id
}

Received 6 November 2019; Accepted 10 April 2020; Available online 27 April 2020

\begin{abstract}
Abstrak
Rumah asuh Baitti Jannatii merupakan rumah asuh dan singgah bagi anak yatim, piatu, dan kaum dhuafa. Dalam menjalankan kegiatan operasionalnya, Rumah Asuh Baitti Jannatii mengandalkan pada bisnis katering dan donatur. Namun, pendanaan tidak dapat diandalkan sepenuhnya kepada bisnis katering dan donatur. Maka diperlukan alternatif lain sebagai sumber pendanaan. Salah satu alternatif yang bisa dilakukan adalah memberikan pelatihan decoupage dengan merubah barang bekas menjadi barang yang bernilai jual tinggi sehingga hasil tersebut dapat dijual. Maka dari itu, pengabdian ini juga memberikan motivasi untuk menumbuhkan jiwa kewirausahaan. Berdasarkan permasalahan mitra maka pengabdian ini bertujuan untuk memberikan pelatihan decoupage serta menumbuhkan jiwa kewirausahaan dalam upaya mencapai kemandirian finansial. Metode pelaksanaan kegiatan dilalui dengan tahap persiapan, tahap pelaksanaan dan tahap evaluasi. Kegiatan pengabdian telah dilaksanakan dan diikuti oleh 20 peserta dengan sangat baik dan antusias. Telah dihasilkan produk decoupage sebanyak 17 kerajinan centong decoupage dan 3 kerajinan piring decoupage. Berdasarkan hasil evaluasi didapatkan bahwa terdapat peningkatan pengetahuan dari peserta pelatihan dan peserta berkeinginan untuk menjadikan berwirausaha dengan memanfaatkan pengetahuan decoupage yang telah didapatkan sehingga akhirnya akan mampu untuk mencapai kemandirian finansial bagi keberlangsungan Rumah Asuh Baitii Jannatii.
\end{abstract}

Kat-kata kunci: decoupage, kewirausahaan, Baitii Jannatii

\section{Abstract}

Baitii Jannatii is a foster home, and its for orphans, and the poor. In carrying out its operational activities, Baitti Jannatii's Foster Home relies on the catering and donors. However, funding cannot entirely rely upon to catering businesses and donors, so they need alternative as a source of funding. One alternative is to provide decoupage training by converting used goods into high-value items so they can sell the product. Therefore, these activities also motivate an entrepreneurial spirit. Based on the problems of partners, this aims to provide decoupage training and the entrepreneurial spirit to achieve financial independence. The method of implementing the activity is through the preparation phase, the implementation phase, and the evaluation phase. The activity was attended by 20 participants 
very well and enthusiastically. Decoupage products have produced as many as 17 centong decoupage crafts and three decoupage plate crafts. Based on the results of the evaluation it was found that there was an increase in knowledge from the trainees and the participants wished to become entrepreneurs by utilizing the knowledge of decoupage that had obtained so that eventually they would be able to achieve financial independence for the sustainability of the Baitii Jannatii Foster House.

Keywords : decoupage, entrepreneurship, Baitii Jannatii

\section{PENDAHULUAN}

Rumah asuh atau rumah singgah tidak hanya menjalankan aktivitas untuk pembinaan terhadap anak asuh mereka, namun tugas dan peranan mereka jauh lebih penting. Peranan penting rumah asuh tidak hanya pembina bagi anak-anak asuh tersebut namun sebagai agen sosialisasi yang akan mentransformasikan anak-anak asuh mereka menjadi pribadi yang lebih baik lagi (Smith, 2006 dalam Sriwartini et al., 2019). Salah satu rumah asuh yang berada di Puwokerto adalah Rumah Asuh Baitii Jannatii. Rumah asuh ini merupakan rumah asuh dan singgah bagi anak yatim, anak piatu dan kaum dhuafa. Rumah Asuh Baitii Jannatii dikelola oleh Tri Budiana Utami, S.Pd.I, Syafriliana NATS, Amd. Keb., dan Gita Chandra Wicakso. Ketiga pengelola ini mulai mendirikan rumah asuh pada 8 April 2016 dan bertempat di Jl. Penatusan I No. 58 RT. 02 RW. 02 Purwokerto Timur.

Sejak 2016 sampai sekarang, rumah asuh ini memiliki anak asuh sebanyak 21 orang dengan rincian yaitu 13 perempuan dan 8 laki-laki. Semua anak asuh ini mengenyam pendidikan formal dari tingkat sekolah dasar sampai perguruan tinggi. Biaya untuk pendidikan anak asuh ini pun tidak sedikit. Selama 3 tahun, pengelolaan keuangan dalam menjalankan operasional rumah asuh dan untuk biaya sekolah anak asuh ditopang oleh pengelola dan donatur. Donatur di rumah asuh Baitii Jannatii dibagi menjadi donatur tetap dan tidak tetap. Donatur tetap adalah donatur yang secara rutin memberikan bantuan kepada Baitii Jannatii sedangkan donatur tidak tetap merupakan donatur yang tidak rutin memberikan bantuan ke rumah asuh Baitii Jannati. Berdasarkan hasil wawancara, donatur tetap pun jumlahnya tidak lebih dari lima orang.

Rumah asuh Baitii Jannati sangat menyadari bahwa tidak bisa terus bergantung pada para donatur dalam memenuhi kebutuhan finansial mereka. Maka dari itu, rumah asuh ini memiliki usaha katering untuk memenuhi kebutuhan finansial dan operasional rumah asuh. Bisnis katering ini cukup berjalan dengan baik dan pemesannya bisa dikatakan lumayan. Usaha bisnis katering ini menjadi pioner dalam menuju kemandirian finasial untuk rumah asuh Baitii Jannatii. Namun, pengelola menyadari bahwa tidak bisa 100 persen bergantung hanya kepada bisnis katering. Karena pernah ada situasi dimana rumah asuh ini tidak mendapatkan pesanan katering sehingga membuat pengelola harus berfikir bagaimana kebutuhan finansial dan biaya operasional rumah asuh bisa didapatkan.

Keadaan ini bisa diatasi dengan membuka alternatif usaha yang harus dijalankan oleh rumah asuh. Alternatifnya adalah dengan memanfaatkan barang-barang bekas yang mudah didapatkan di lingkungan sekitar agar diolah menjadi produk yang bernilai jual. Permasalahan lainnya adalah di rumah asuh tersebut belum pernah diadakan pelatihan peningkatan skill bagi anak-anak asuh Baitii Jannatii. Padahal tujuan dari rumah asuh adalah menciptakan kemandirian pada anak asuh mereka dengan ditunjang pendidikan formal maupun non formal. Para donatur memiliki kecenderungan hanya memberikan sumbangan berupa dana atau bantuan lainnya yang tidak berhubungan dengan pengembangan diri anak asuh di Baitii Jannatii. Pengembangan diri dan peningkatan skill diperlukan tidak hanya berguna bagi rumah asuh tersebut namun lebih diutamakan untuk anak-anak asuh tersebut. Peningkatan skill di dalam keterampilan diyakini mampu menjadi sumber yang tidak ternilai. 
Salah satu alternatifnya adalah memanfaatkan barang bekas yang dirubah menjadi produk bernilai ekonomis. Faktor utama pemilihan barang bekas adalah karena bertujuan untuk mencari pemasukan maka alat dan bahan pelatihan yang diperlukan pun harus terjangkau dan mudah didapatkan. Pelatihan dalam merubah barang bekas dengan teknik decoupage bisa menjadi alternatif bagi rumah asuh Baitii Jannati dalam mencari pemasukan secara mandiri. Decoupage salah satu cara yang menyenangkan untuk mendekorasi objek apa pun dan relatif mudah dipelajari hanya dengan beberapa langkah (Nurlaila \& Yulastri, 2017). Tujuan decoupage pada dasarnya merubah barang-barang atau objek yang dipilih sehingga memiliki nilai jual dari produk itu sendiri (Nurmaya et al., 2019).

Dengan kata lain, teknik decoupage merupakan suatu teknik menempelkan kertas tisue yang disebut napkin ke suatu objek. Tisue yang digunakan sangat berbeda dengan tisue biasa, karena tisue tersebut sudah berpola tertentu sehingga hanya tinggal menggunting dan menempelkan ke objek (Sulistyowati, Iqbal, \& Murni, 2018). Solusi ini dilakukan untuk mendorong jiwa berwirausaha dari anak-anak rumah asuh Baitii Jannatii. Murni et al., (2018) menyatakan munculnya jiwa kewirausahaan dalam diri individu akan memberi manfaat secara finansial maupun non-finansial. Secara finansial artinya muncul kemandirian finansial dan secara non-finansial menumbuhkan mentah tangguh dan pantang menyerah. Atas dasar inilah tim pelaksana mengadakan pengabdian pelatihan decoupage agar dapat menumbuhkan jiwa kewirausahaan untuk anak asuh Rumah Asuh Baitii Jannatii.

\section{METODE PELAKSANAAN}

Metode pelaksanaan untuk pengabdian ini melalui beberapa tahapan, yaitu dimulai dengan tahap persiapan, tahap pelaksanaan dan tahap evaluasi. Masing-masing metode pelaksanaan ini akan dijabarkan sebagai berikut:

a. Tahap persiapan

Tahap persiapan kegiatan dilaksanakan dengan berkoordinasi dengan mitra dalam hal ini Rumah Asuh Baitii Jannatii Purwokerto untuk menentukan waktu kegiatan dan kegiatan yang akan dilaksanakan. Kegiatan pengabdian ini ditujukan bagi anak-anak asuh di Baitti Jannatii. Berdasarkan saran dari pengelola Baitti Jannatii, kegiatan pengabdian dilaksanakan ketika hari libur agar dapat diikuti oleh seluruh anak asuh. Pemilihan hari libur dikarenakan anak-anak asuh masih menempuh pendidikan formal dari SD sampai perguruan tinggi. Lokasi kegiatan berada di Rumah Asuh Baitti Jannatii.

Persiapan yang perlu dilakukan selanjutnya adalah menghubungi narasumber yang memberi pelatihan mengenai decoupage. Berdasarkan wawancara dengan narasumber didapatkan bahwa materi yang akan diberikan kepada anak asuh adalah decoupage pada bidang datar seperti centong dan piring. Pemilihan materi decoupage pada centong dan piring dikarenakan anak asuh belum mengenal decoupage dan media datar merupakan media paling mudah. Untuk alat dan bahan dalam pelaksanaan kegiatan ini disediakan oleh pihak pelaksana dan narasumber.

b. Tahap pelaksanaan

Langkah selanjutnya adalah tahap pelaksanaan kegiatan pengabdian. Pelaksanaan kegiatan pengabdian akan dilaksanakan selama satu hari yang dibagi dengan menjadi dua sesi kegiatan. Sesi pertama akan difokuskan pada pemberian materi mengenai decoupage dan motivasi dalam membangun jiwa kewirausahaan. Materi mengenai decoupage akan berisi mengenai gambaran mengenai apa itu decoupage, apa saja yang bisa dijadikan kerajinan decoupage serta alat dan bahan yang digunakan. Selain itu, sesi pertama juga diberikan motivasi berwirausaha untuk kerajinan decoupage. Hal ini sesuai dengan tujuan pelaksanaan kegiatan pengabdian yang berusaha menjawab permasalahan di mitra dengan memberikan pelatihan dan motivasi kewirausahaan agar tercapai kemandirian finansial. Pada sesi pertama juga sudah dilakukan untuk pembuatan decoupage pada centong, Sesi 
kedua dalam kegiatan pengabdian akan praktik langsung dalam pembuatan kerajinan decoupage dari piring yang akan diajarkan oleh narasumber. Cara pembuatan akan diterangkan dengan step by step oleh narasumber sehingga semua anak asuh dapat membuat kerajinan decoupage.

c. Tahap evaluasi

Tahap terakhir dari kegiatan ini adalah tahap evaluasi kegiatan. Evaluasi dilakukan dengan melakukan wawancara kepada peserta pelatihan dan pengelola dari Rumah Asuh Baitii Jannatii. Evaluasi ini dilakukan guna memberikan masukan perbaikan untuk kegiatan lanjutan pengabdian yang lebih baik.

\section{HASIL DAN PEMBAHASAN}

Pelaksanaan kegiatan dilakukan pada Minggu, 14 Juli 2019 di Rumah Asuh Baitii Jannatii dengan diikuti oleh 20 peserta. Pengabdian ini juga melibatkan narasumber untuk mengajarkan pelatihan decoupage. Kegiatan berlangsung dari pukul pukul 08.00 sampai dengan pukul 16.00 WIB. Rincian pelaksanaan kegiatan pengabdian ini dapat dilihat pada Tabel 1.

Tabel 1. Rincian Jadwal Pelaksanaan Kegiatan Pengabdian

\begin{tabular}{|c|c|c|c|}
\hline Tanggal & Waktu & Materi & Penyaji \\
\hline 14 Juli 2019 & $\begin{array}{l}08.00-08.15 \\
08.15-09.30\end{array}$ & $\begin{array}{l}\text { Pembukaan } \\
\text { Penjelasan tentang teknik } \\
\text { decoupage, motivasi } \\
\text { kewirausahaan serta diskusi } \\
\text { Praktek pemanfaatan } \\
\text { centong bekas dengan } \\
\text { teknik decoupage }\end{array}$ & $\begin{array}{l}\text { Tim pelaksana } \\
\text { dan narasumber }\end{array}$ \\
\hline 14 Juli 2019 & $13.00-16.00$ & $\begin{array}{l}\text { Praktek pemanfaatan piring } \\
\text { dengan teknik decoupage }\end{array}$ & $\begin{array}{l}\text { Tim pelaksana } \\
\text { dan narasumber }\end{array}$ \\
\hline
\end{tabular}

Penjabaran mengenai masing-masing kegiatan akan dipaparkan sebagai berikut:

a. Sesi Pertama

Sesi pertama dimulai dengan pemaparan secara singkat mengenai apa itu decoupage. Anak asuh di Baitii Jannatii ternyata belum mengetahui apa itu decoupage, sehingga narasumber menjelaskan dengan memberi contoh barang-barang yang telah dibuat dengan sentuhan decoupage. Awalnya banyak peserta yang tidak paham contoh kerajinan dengan teknik decoupage, namun ketika melihat contoh hasil kerajinan decoupage, banyak anakanak yang paham namun tidak mengetahui bahwa itu dibuat dengan teknik decoupage. Narasumber kemudian menjelaskan pengertian decoupage dan menjelaskan alat serta bahan yang dibutuhkan. Proses tanya jawab juga terjadi antara narasumber dan peserta pelatihan. Umumnya peserta mengajukan pertanyaan mengenai alat dan bahan tersebut bisa didapatkan dari mana. Setelah itu, tim pelaksana memberikan motivasi mengenai kewirausahaan, yang menyangkut tentang kelebihan menjadi wirausaha dan cara memulai suatu bisnis sendiri. Sebagian peserta pelatihan sudah ada yang pernah memulai bisnis kecil-kecilan namun akhirnya tidak berlanjut. Namun, peserta tersebut mengakui bahwa dengan berbisnis, dia mampu untuk minimal membeli perlengkapan sekolah sendiri.

Kegiatan selanjutnya adalah praktik decoupage. Peserta pelatihan masing-masing diberikan satu centong dan dibebaskan dalam berkreasi dalam memilih tisu decoupage dengan berbagai macam motif yang ada di tisu decoupage. Tujuan untuk bebas memilih ini, untuk menunjukkan sisi kreatifitas anak-anak dalam berkreasi. Selain itu, sebagai 
asesoris tambahan dalam mempercantik centong hasil decoupage maka diajarkan pula membuat pita dari kain. Kegiatan sesi pertama, pelatihan centong dengan teknik decoupage untuk anak asuh Baitii Jannatii. Dalam pelatihan ini, anak asuh di Baitii Jannatii juga diajarkan membuat pita dari kain yang akan digunakan sebagai asesoris tambahan dari decoupage.
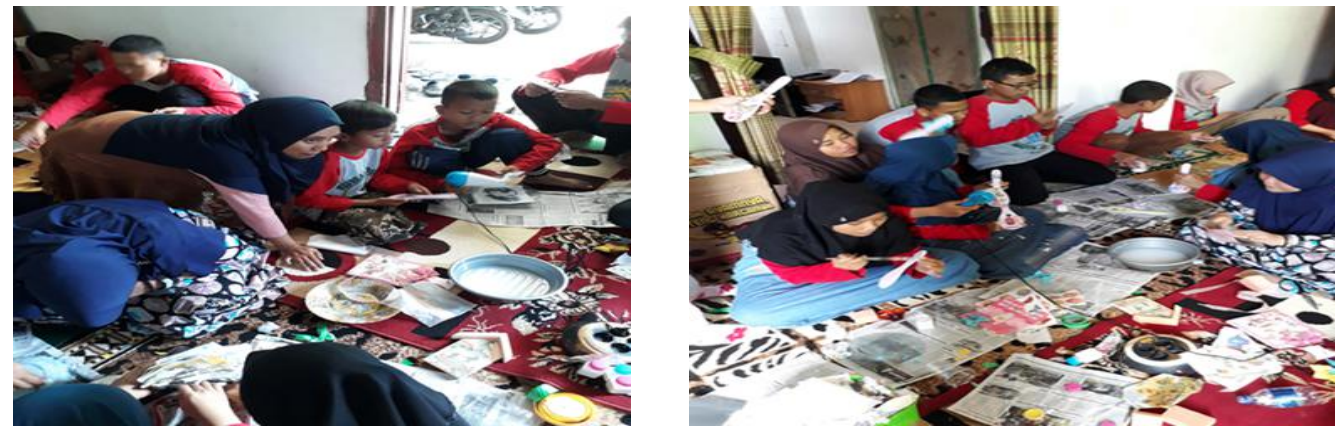

Gambar 1. Kegiatan Sesi Pertama

\section{b. Sesi Kedua}

Sesi kedua dilanjutkan setelah istirahat dengan mengajarkan teknik decoupage pada piring. Cara kerja yang sama seperti pada centong namun karena piring memiliki lebar yang lebih luas sehingga membutuhkan waktu yang lebih lama dalam menerapkan teknik decoupage di piring. Letak kesulitan terdapat pada bidang cekung piring dalam menempelkan tisu decoupage. Meskipun begitu, peserta pelatihan mampu melakukan dan berkreasi pada media piring dengan baik. Beberapa hasil kreasi kerajinan decoupage pada centong dan piring dapat dilihat pada gambar 2 .
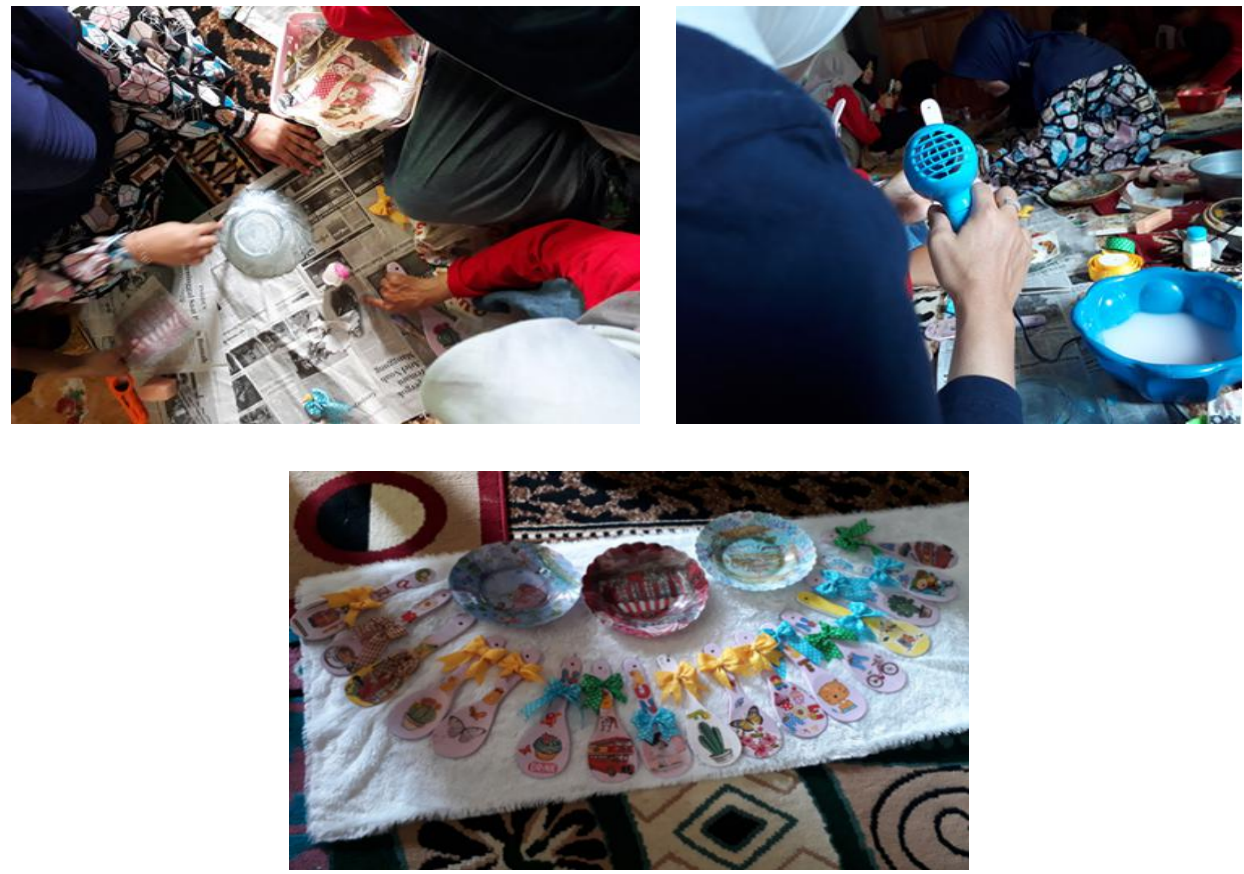

Gambar 2. Kegiatan Sesi Kedua dan Hasil Kerajinan

Setelah proses pelaksanaan kegiatan dilaksanakan maka dilakukan evaluasi terhadap kegiatan yang telah dilaksanakan. Secara keseluruhan acara pelatihan ini berjalan dengan sangat baik dan diikuti dengan antusias dari peserta pelatihan. Peserta pelatihan mampu mengikuti pelatihan yang memakan waktu satu hari tanpa meninggalkan kegiatan pelatihan. Anak asuh Baitii Jannatii mampu menerima semua materi dan mengaplikasikan ilmu 
decoupage secara langsung. Beberapa peserta tertarik untuk mendalami kerajinan decoaupage lebih lanjut agar dapat memulai bisnis decoupage. Meskipun berjalan dengan baik, pelaksanaan pengabdian ini memiliki beberapa kendala yaitu kurangnya alat penunjang untuk kegiatan seperti hairdryer yang hanya tersedia satu buah sehingga harus mengantri dalam mengeringkan. Kelebihan dari kegiatan pengabdian ini adalah memberikan pengetahuan baru untuk anak asuh dalam menumbuhkan jiwa kewirausahaan dengan berani berkreasi mendaur ulang barang-barang bekas dengan teknik decoupage sehingga memiliki nilai jual.

\section{KESIMPULAN}

Tujuan pengabdian telah tercapai dengan mentransfer pengetahuan kepada anak asuh Baitii Jannatii mengenai keterampilan dalam merubah barang bekas menjadi produk baru dengan menggunakan teknik decoupage. Anak asuh Baitii Jannatii mampu berkreasi dengan sangat baik dan mengikuti proses pelatihan dengan antusias. Pemilihan keterampilan ini juga berusaha mendorong keinginan atau jiwa wirausaha di dalam diri anak-anak asuh Baitii Jannatti sehingga akhirnya akan mampu untuk mencapai kemandirian finansial bagi keberlangsungan Rumah Asuh Baitii Jannatti. Meskipun, belum sampai menerapkan penjualan terhadap produk decoupage, pengetahuan baru ini diharapkan mampu dimanfaatkan oleh anak asuh untuk mendukung kemandirian finansial. Maka dari itu, saran untuk pengabdian berikutnya bisa difokuskan pada pemberian keterampilan decoupage lain yang lebih kompleks atau dengan memberi pengetahuan mengenai internet marketing sebagai sarana dalam memasarkan produk hasil kreasi anak asuh Baitii Jannatii.

\section{UCAPAN TERIMA KASIH}

Penulis mengucapkan terima kasih kepada LPPM Universitas Amikom Purwokerto atas hibah Amikom dalam skim pengabdian yaitu Amikom Mitra Masyarakat, kepada pengelola dan anak asuh Rumah Asuh Baitti Jannatii atas kerjasamanya dalam pelaksanaan kegiatan Amikom Mitra Masyarakat, serta kepada narasumber yang berkenan bekerja sama dengan pelaksana dalam memberi pelatihan sehingga kegiatan Amikom Mitra Masyarakat dapat berjalan dengan baik.

\section{DAFTAR PUSTAKA}

Murni, Y., Hirdinis, \& Iqbal, M. A. 2018. Pelatihan Decoupage Bagi Masyarakat Kampung Sawah, Kota Bekasi. Jurnal MITRA, 2(1), 65-76.

Nurlaila, \& Yulastri, L. 2017. Pemberdayaan Ibu-Ibu PKK Kelurahan Rawamangun Dalam Pelatihan Pembuatan Decoupage Dari Tissue Berbasis Industri Kreatif. Sarwahita, 14(02), 151-155. https://doi.org/10.21009/sarwahita.142.10

Nurmaya, Diana, N. E., Kurnianingsih, I., \& Rosini. 2019. Pelatihan Peningkatan Nilai Produk Kerajinan Tangan Decoupage dan Pemasaran Produk untuk Ibu Rumah Tangga. MATAPPA: Jurnal Pengabdian Kepada Masyarakat, 2(1), 53-59.

Sriwartini, Y., Radjagukguk, D. L., \& Masnah. 2019. Pendampingan Membuat Decoupage dan Pemasarannya Melalui Media Online. Jurnal ABDINUS : Jurnal Pengabdian Nusantara, 2(2), 181-190.

Sulistyowati, N., Iqbal, M. A., \& Murni, Y. 2018. PKM Kerajinan Decoupage di Kelurahan Katulampa, Bogor Timur. In Konferensi Nasional PkM-CSR Ke-4 (pp. 23-25). 